\title{
RAINFALL THRESHOLDS FOR LANDSLIDE IN GARUT REGENCY, WEST JAVA USING HIMAWARI-8 DATA
}

\author{
Jalu Tejo Nugroho', Nanik Suryo Haryani' ${ }^{2}$, Fajar Yulianto ${ }^{3}$, Mohamad Ardha ${ }^{4}$ \\ Remote Sensing Application Center, LAPAN \\ Jl. Kalisari No. 8 Pekayon Pasar Rebo, Jakarta, 13710, Indonesia \\ e-mail: jalu.tejo@lapan.go.id
}

Received: 11 May 2020, Repaired: 23 December 2020, Approved: 27 January 2021

\begin{abstract}
Landslide was one of natural disasters that affected by the weather. The intensity of landslide in Indonesia tended to increase from year to year with a larger area distribution. Remote sensing was a method that can be used to support disaster mitigation and response activities including landslide because this technology allows monitoring and analysis both spatially and temporally. One of the remote sensing satellites that can be used for monitoring landslide was Himawari-8. This weather satellite was launched in 2014 and had a temporal resolution of 10 minutes making it effective for meteorological, environmental and disaster observations. This research has used Himawari-8 rainfall data which extracted from cloud top temperature to determine the intensity of rainfall that causes landslide in Garut Regency. The daily accumulation of rainfall for five days before the landslide event up to five days after the landslide event has been investigated statistically to analyze the conditions of rainfall that trigger landslides. Rainfall thresholds for landslide was determined by the intensity maximum of daily accumulation. It was found that the intensity of rainfall that has potential to cause landslides based on the threshold value is as follows: Malangbong District $60.3 \mathrm{~mm} /$ day, Banjarwangi District $32.3 \mathrm{~mm} /$ day, Pasirwangi District $36.9 \mathrm{~mm} /$ day, Cisewu District $35.1 \mathrm{~mm} /$ day and Talegong District $52.8 \mathrm{~mm} /$ day. Landslide in four districts have corresponded with the day where the intensity of rainfall was maximum. Meanwhile for Talegong District, the landslide was occurred a day after its maximum.
\end{abstract}

Keywords: rainfall, Himawari-8, landslide, remote sensing, threshold

\begin{abstract}
Abstrak
Longsor merupakan salah satu bencana alam yang dipengaruhi oleh cuaca. Intensitas longsor di Indonesia cenderung meningkat dari tahun ke tahun dengan sebaran wilayah yang lebih luas. Penginderaan jauh merupakan metode yang dapat digunakan untuk mendukung kegiatan mitigasi dan tanggap bencana termasuk longsor karena teknologi ini memungkinkan pemantauan dan analisis baik secara spasial maupun temporal. Salah satu satelit penginderaan jauh yang dapat digunakan untuk pemantauan longsor adalah Himawari-8. Satelit cuaca ini diluncurkan pada tahun 2014 dan memiliki resolusi temporal 10 menit sehingga efektif untuk pengamatan meteorologi, lingkungan dan bencana. Penelitian ini menggunakan data curah hujan Himawari-8 yang diekstrak dari suhu puncak awan untuk mengetahui intensitas curah hujan penyebab longsor di Kabupaten Garut. Akumulasi curah hujan harian selama lima hari sebelum kejadian longsor sampai dengan lima hari setelah kejadian longsor diteliti secara statistik untuk menganalisis kondisi curah hujan yang memicu terjadinya longsor. Ambang batas curah hujan untuk longsor ditentukan oleh intensitas maksimum akumulasi harian. Diketahui bahwa intensitas curah hujan yang berpotensi menimbulkan longsor berdasarkan nilai ambang batas adalah sebagai berikut: Kecamatan Malangbong 60,3 mm / hari, Kecamatan
\end{abstract}


Banjarwangi 32,3 mm / hari, Kecamatan Pasirwangi 36,9 mm / hari, Kecamatan Cisewu 35,1 $\mathrm{mm} /$ hari dan Kecamatan Talegong 52,8 $\mathrm{mm} / \mathrm{hari}$. Tanah longsor di empat kecamatan telah sesuai dengan hari dimana intensitas curah hujan maksimal. Sedangkan untuk Kecamatan Talegong, longsor terjadi sehari setelah maksimumnya.

\section{Kata kunci: curah hujan, Himawari-8, longsor, penginderaan jauh, ambang batas}

\section{INTRODUCTION}

Landslide is a geological event that occurs due to mass movement of rock or soil which then falls on the material underneath it. National Agency for Disaster Management (BNPB) has stated that the landslide is the third most common hydrometeorological disasters in Indonesia after flood and a tornado, with the number of 577 events (BNPB, 2017).

In addition to the rainfall factor (Iverson 2000; Zhang et al., 2018) landslide is also caused by several triggering factors, whether originating from nature such as geological and geomorphological conditions (McColl, 2015), earthquakes (Huang, 2014; $\mathrm{Xu}$ et al., 2018) or human activities that contribute to changes in land use.

Landslide that has occurred in several regions in Indonesia are commonly triggered by a change in land use, from perennial vegetation types (hardwood) into plantation fields and settlements which reduce the ability of the vegetation to maintain the groundwater (Hadmoko, Lavigne, \& Sartohardi, 2017; Marfai et al., 2008; Sitorus \& Pravitasari, 2017).

Nowadays remote sensing technology has applied for landslide detection, including spatial mapping, monitoring of surface deformation, modeling related to regional vulnerability, hazard assessment, and disaster risk evaluation and analysis of the triggering factors, including rainfall (Zhao \& Lu, 2018). This study utilizes remote sensing satellite data which has sufficient historical data to detect and monitor landslide, which are triggerd by rainfall.

Himawari-8 is a weather satellite operated by the Japan Meteorological Agency (JMA) for meteorological and environmental observations. This satellite has 16 bands with a spatial resolution of 1 to
$2 \mathrm{~km}$ and a temporal resolution of 10 minutes. Since launched in 2014, Himawari8 data has been widely applied in various sectors, such as weather forecasting (Ma, Maddy, Zhang, Zhu, \& Boukabara, 2017), environmental and climate monitoring (Kushardono, 2012; Okumura et al., 2016; Shang, Letu, Peng, \& Wang, 2018) and also disaster risk reduction (Marchese, Falconieri, Pergola, \& Tramutoli, 2018; Na et al., 2018; Wickramasinghe, Jones, Reinke, \& Wallace, 2016). High temporal resolution of Himawari-8 is very effective for near realtime monitoring including rainfall variability.

The rainfall estimation was extracted from Himawari-8 data that determined by cloud top temperature in the IR-1 band with a wavelength of $10.4 \mu \mathrm{m}$. The colder of cloud top temperature related with cloud growth and cloud formation of Cumulonimbus which tend to increase rainfall intensity. There were several methods that can be used to estimate rainfall from cloud top temperature, including Multispectral Rainfall Algorithm (IMSRA). In this study, IMSRA algorithm was used in calculating the estimated rainfall which is extracted from the Himawari-8 data. In several studies, this method provided better accuracy results than others. (Gairola, Varma, Prakash, \& Mahesh, 2011; Alfuadi \& Wandala, 2016).

As one of the factors causing landslide, determining the threshold for rainfall that triggers landslides was important. Rainfall threshold was defined as a rainfall limit condition which could lead to slope failure and landslide (Guzzetti, Peruccacci, Rossi \& Stark, 2007). Rainfall conditions can be evaluated from duration, accumulation, or intensity. The threshold value can be determined both theoretically (based on physical, conceptual processes) and empirically based on historical data/ 
statistics. (Corominas \& Moya, 1996; Crosta \& Frattini, 2003). The purpose of research is to determine rainfall thresholds for landslide activity Garut Regency, West Java based on Himawari-8 data.

\section{DATA AND METHOD}

Data

10 minutes time series of rainfall data derived from Himawari-8 sattelite were collected in this study. The data were obtained from Remote Sensing Technology and Data Center (Pustekdata), LAPAN and record spanned a period during November 2017 at $4 \mathrm{~km}$ spatial resolution. In addtion, shapefile boundary map, land use land cover (LULC) map, slope map from Geospatial Information Agency, landslide hazards index data from BNPB and other relevant data were investigated to support the analysis.

Study area and field checking of landslide was located at five districts in Garut Regency; Cisewu District, Talegong District, Banjarwangi District, Pasirwangi District and Malangbong District. Garut Regency was chosen as the research location because this region was one of region with the highest landslide risk index in Indonesia (BNPB, 2014). Geographically, Garut Regency was located at $107^{\circ} 25^{\prime} 8^{\prime \prime}-108^{\circ} 7^{\prime} 30^{\prime \prime}$ E and 6 $56^{\prime} 49^{\prime \prime}-7^{\circ} 45^{\prime} 00^{\prime \prime} \mathrm{S}$. Northern part of the Garut Regency was bordered with Majalengka Regency and Sumedang Regency, eastern part with Tasikmalaya Regency, southern part with Indian Ocean and western part with Bandung Regency and Cianjur Regency. Figure 1 displayed the location of our study.

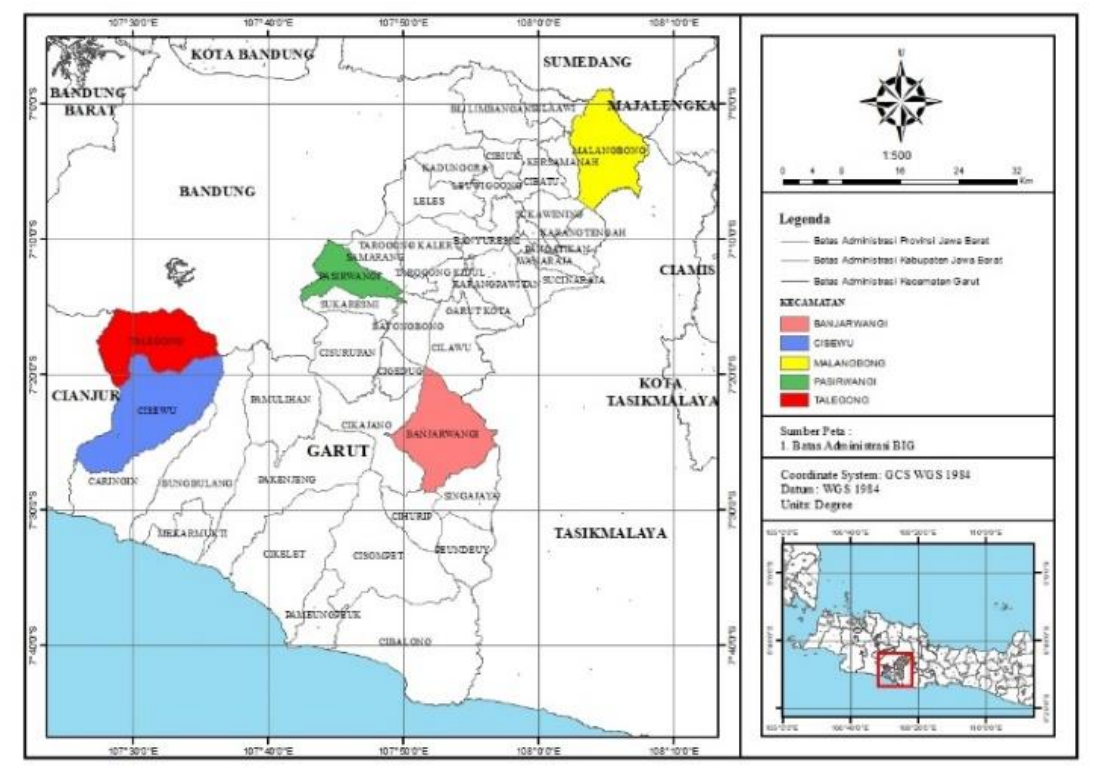

Figure 1. Map of study area in Garut Regency, West Java

\section{Method}

The method used in this study was a statistical method, in which the daily rainfall accumulation value was obtained from 10 minutes data. This process was performed from five days before the landslide to five days after the landslide occured.

At first stage a landslide historical data was collected. The next step was checked the rainfall condition using
Himawari-8 data for five days before landslide to five days after the landslide event and then accumulated the daily value calculated from 10 minutes data. The threshold value of rainfall that triggers landslides is determined from the maximum daily intensity of rainfall at the day of the landslide. Finally, the threshold was overlaid with a landslide risk map to obtain the landslide level of vulnerability 
information. Flowchart of the research was shown in Figure 2.

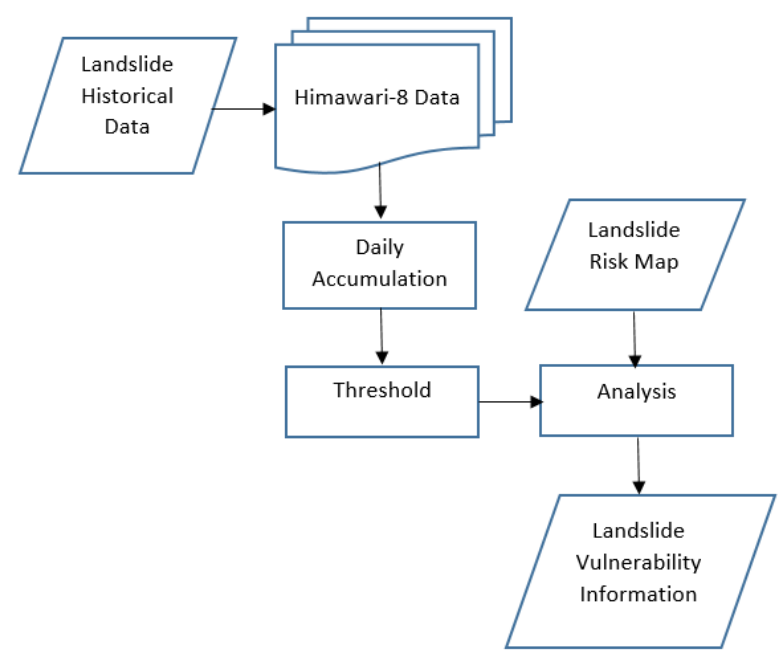

Figure 2. Flowchart of research methodology

\section{RESULT AND DISCUSSION}

\section{Rainfall Thresholds for Landslide}

Landslide in Malangbong District, Garut Regency on November 22, 2017 was detected when the average daily rainfall intensity was $52.6 \mathrm{~mm} /$ day, with the minimum and maximum daily rainfall ranging from $44.9 \mathrm{~mm} /$ day to $60.3 \mathrm{~mm} /$ day. From the calculation of the daily accumulation of rainfall intensity for five days prior to the landslide event it was known that on November 17, 2017 the average daily rainfall intensity reached 24.1 $\mathrm{mm} /$ day with a maximum value of 15.0 $\mathrm{mm} /$ day and a minimum of $18.2 \mathrm{~mm} /$ day. On November 18, 2017 no rain was detected. Meanwhile, on November 19, 2017 and November 20, 2017 low intensity rain was detected with a daily average of $3.6 \mathrm{~mm} /$ day to $4.5 \mathrm{~mm}$ /day and on November 21, 2017 the intensity of rainfall increased to around 40.6. $\mathrm{mm}$ /day up to $44.6 \mathrm{~mm} /$ day.

The condition after the landslide incident on November 23, 2017, there was rain with an intensity decreasing by 19.6 $\mathrm{mm} /$ day to $35.4 \mathrm{~mm} /$ day. On November 24, 2017 the intensity of the rain increased to $25.8 \mathrm{~mm} /$ day to $30.9 \mathrm{~mm} /$ day. On November 25, 2017 the condition of the rainfall again decreased sharply to 4.1 $\mathrm{mm} /$ day to $5.6 \mathrm{~mm} /$ day. On November 26 and November 27, 2017 the intensity of rainfall again increased, ranging from 29.4 $\mathrm{mm} /$ day to $34.7 \mathrm{~mm} /$ day. Figure 3 showed the minimum and maximum rainfall conditions during the landslide event on November 22, 2017 in Malangbong District, Garut Regency.

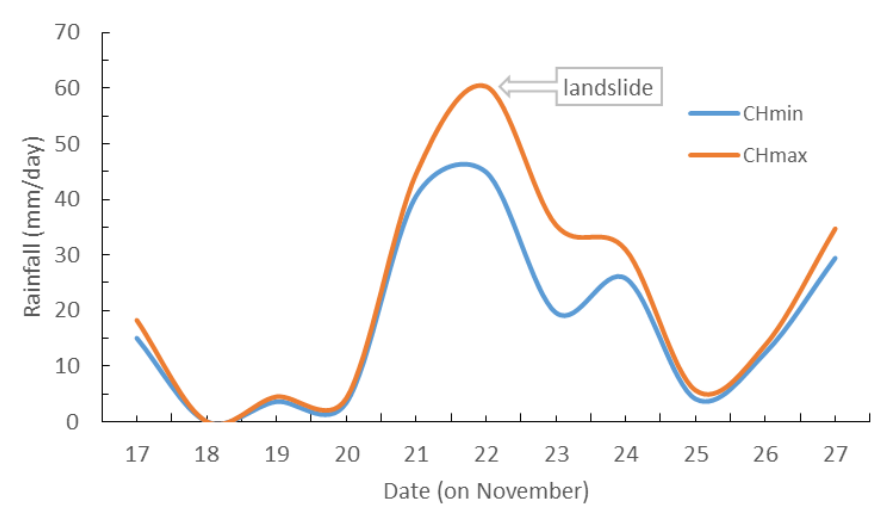

Figure 3. Accumulated daily rainfall intensity on November 17 to November 27, 2017 in Malangbong District, Garut Regency as detected from Himawari-8 data 
The estimated rainfall of Himawari-8 data that occurred at the time of landslide in Pasirwangi District on November 14, 2017 ranged from $26.1 \mathrm{~mm} /$ day to $36.9 \mathrm{~mm} /$ day with an average value of $16.5 \mathrm{~mm} /$ day. On November 9, 2017 no rain was detected while on November 10, 2017 low intensity rainfall was observed between $12.6 \mathrm{~mm} /$ day to $13.2 \mathrm{~mm} /$ day. On November 11 and November 12, 2017 the rainfall decreased with an intensity between $5.5 \mathrm{~mm} /$ day to $12.8 \mathrm{~mm} /$ day and on November 13, 2017 the rainfall increased to $13.9 \mathrm{~mm}$ /day to 16.9 $\mathrm{mm} /$ day. Meanwhile, the day after the landslide on November 15, 2017, the intensity of the rainfall decreased from 4.5 $\mathrm{mm} /$ day to $4.9 \mathrm{~mm} /$ day. On November 16, 2017 the intensity increased to $14.2 \mathrm{~mm} /$ day to $15.1 \mathrm{~mm} /$ day and on November 17, 2017 it increased with an intensity ranging from $16.6 \mathrm{~mm} /$ day to $18.7 \mathrm{~mm} /$ day. On November 18 and November 19, 2017 the intensity of rainfall was observed decreased with an intensity between $0.3 \mathrm{~mm}$ day to 3.4 $\mathrm{mm} /$ day. Daily rainfall conditions during the landslide event in Pasirwangi District, Garut Regency was shown in Figure 4.

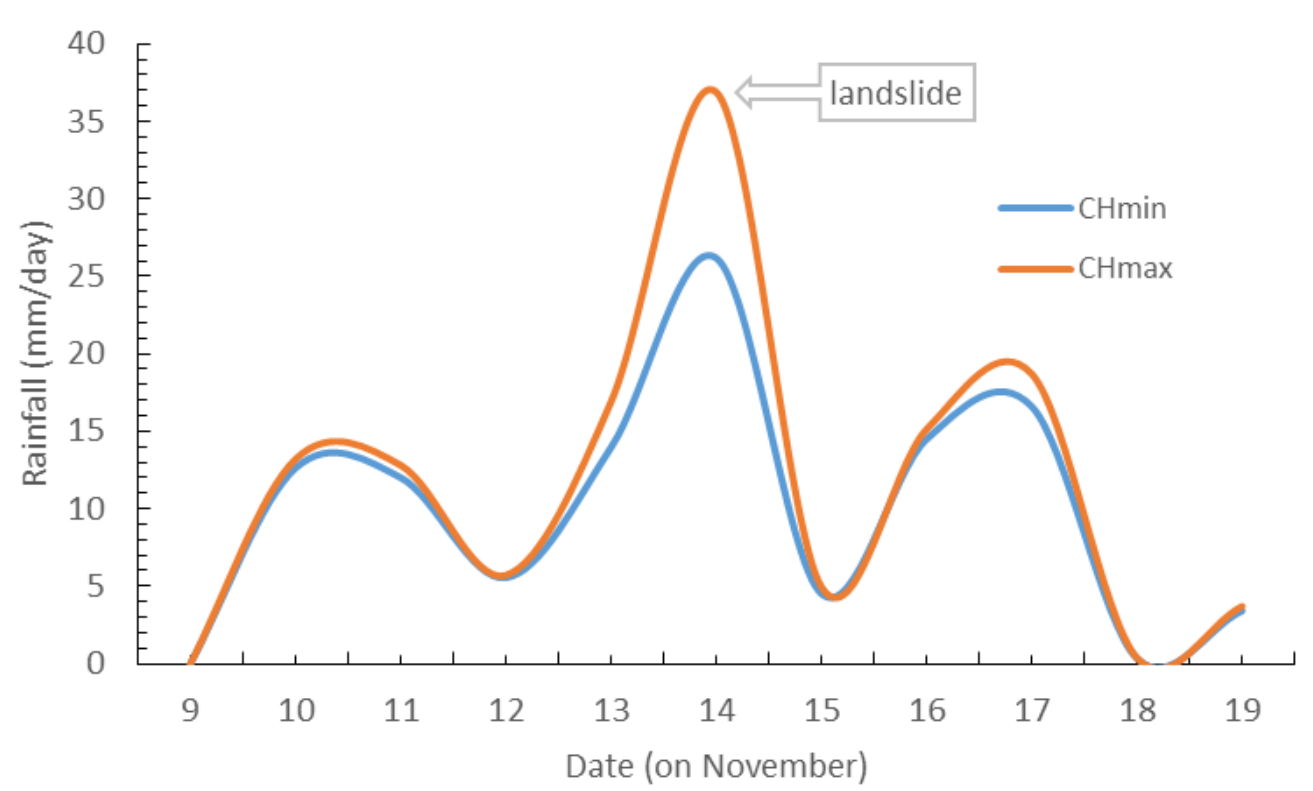

Figure 4. Accumulated daily rainfall intensity on November 9 to November 19, 2017 in Pasirwangi District, Garut Regency as detected from Himawari-8 data

In the case of landslide in Banjarwangi District on November 14, 2017 rainfall was observed with intensities from $29.9 \mathrm{~mm} /$ day to $32.3 \mathrm{~mm} /$ day with an average value of $31.1 \mathrm{~mm} /$ day. On November 9, 2019 no rainfall was detected and it was just detected on November 10, 2017 with low intensity, between 9.7 $\mathrm{mm} /$ day to $11.7 \mathrm{~mm} /$ day. On November 11 and November 12, 2017 rainfall decreased slightly with intensities ranging from 3.1 $\mathrm{mm} /$ day to $8.7 \mathrm{~mm} /$ day. The intensity of rainfall was increased and reach 16.4 $\mathrm{mm} /$ day to $19.1 \mathrm{~mm} /$ day on November 13, 2017.
After the landslide incident on November 15, 2017 the intensity of the rainfall decreased, reaching $4.2 \mathrm{~mm} /$ day to $5.3 \mathrm{~mm} /$ day. On November 16, 2017 the rainfall increased to $16.4 \mathrm{~mm}$ / day up to 19.2 $\mathrm{mm} /$ day and on November 17, 2017 the intensity was between $16.3 \mathrm{~mm} /$ day to 18.8 $\mathrm{mm} /$ day. There was no rainfall detected on November 18 and November 19, 2017. Daily rainfall conditions during the landslide event in Banjarwangi District, Garut Regency was shown in Figure 5. 


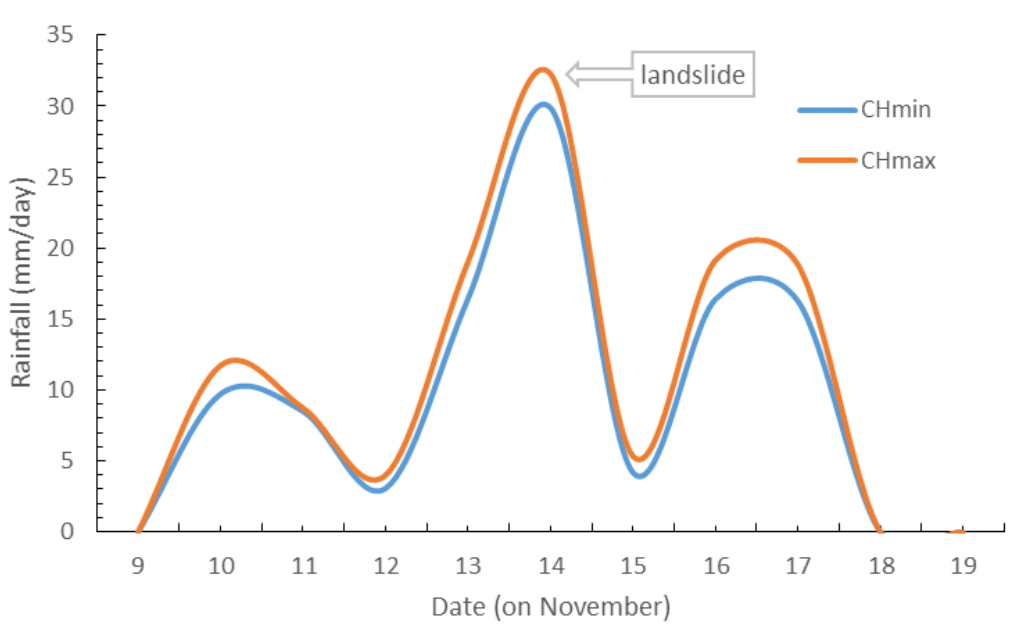

Figure 5. Accumulated daily rainfall intensity on November 9 to November 19, 2017 in Banjarwangi District, Garut Regency as detected from Himawari-8 data

During the landslide in Cisewu District on November 14, 2017 the rainfall conditions from Himawari-8 detection reached $32.4 \mathrm{~mm} /$ day to $35.1 \mathrm{~mm} /$ day with an average value of $33.7 \mathrm{~mm} /$ day. No rainfall was observed on November 9, 2017 while on November 102017 low intensity of rainfall was detected around $5.4 \mathrm{~mm} /$ day to $7.4 \mathrm{~mm} /$ day. There was an increase in rainfall on November 11, 2017 until the intensity reached $11.3 \mathrm{~mm} /$ day to 15.6 mm/day. On November 12, 2017, there was a decrease in rainfall with a range of 2.4 $\mathrm{mm} /$ day to $3.9 \mathrm{~mm} /$ day. The rainfall was increased up to $8.3 \mathrm{~mm} /$ day to $11.4 \mathrm{~mm} /$ day on November 13, 2017.

One day after landslide on November 15, 2017 the rainfall conditions a sharp decreased between $0.5 \mathrm{~mm} /$ day to 1.7 $\mathrm{mm} /$ day, On November 16, 2017 rainfall reached $7.4 \mathrm{~mm} /$ day to $9.8 \mathrm{~mm} /$ day and on November 17, 2017 there was increased of 15.8 $\mathrm{mm} /$ day to $17.3 \mathrm{~mm} /$ day. Rainfall was detected $0.2 \mathrm{~mm} /$ day to $0.5 \mathrm{~mm} /$ day on November 18, 2017 and $2.1 \mathrm{~mm} /$ day to 2.6 mm / day on November 19, 2017. Figure 6 showed the daily rainfall conditions during the landslide event in Cisewu District, Garut Regency.

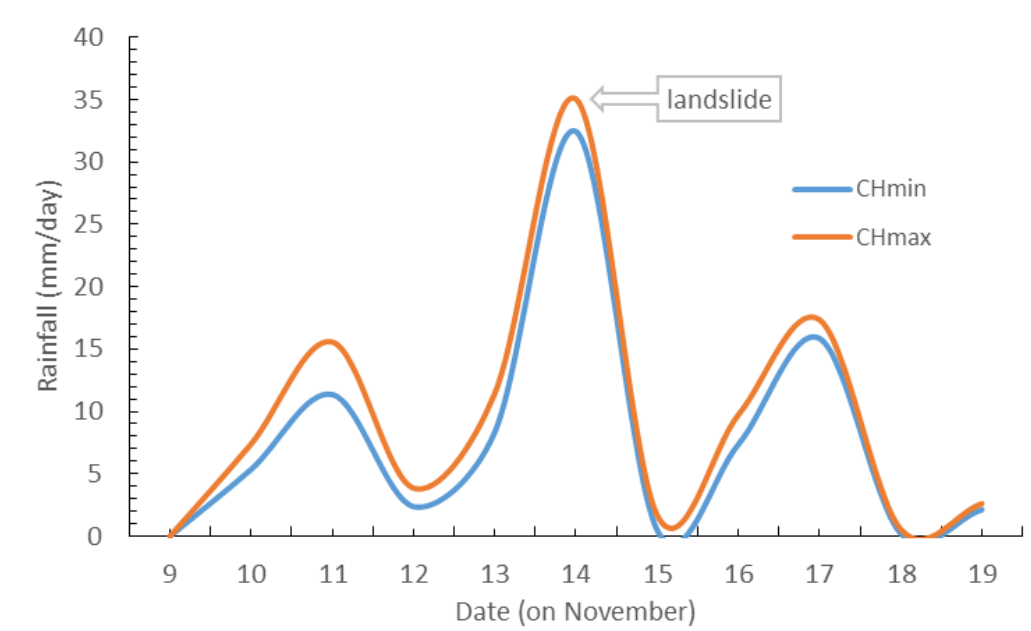

Figure 6. Accumulated daily rainfall intensity on November 9 to November 19, 2017 in Cisewu District, Garut Regency as detected from Himawari-8 data

Rainfall conditions during landslide on November 23, 2017 in Talegong District was detected at $7.7 \mathrm{~mm} /$ day to 13.6 $\mathrm{mm} /$ day with an average of $10.6 \mathrm{~mm} /$ day. 
On November 18, 2017 rainfall was detected around $0.3 \mathrm{~mm} /$ day to $0.5 \mathrm{~mm} /$ day and on November 19 and November 20, 2017 it increased to $0.6 \mathrm{~mm} /$ day to $3.1 \mathrm{~mm} /$ day. In this case it was suggested that rainfall triggered landslides occurred one day before the incident (on November 22, 2017) with the intensity about $47.3 \mathrm{~mm} /$ day to 52.8 $\mathrm{mm} /$ day. Meanwhile on November 21, 2017 the rainfall was monitored $34.2 \mathrm{~mm} /$ day to $41.3 \mathrm{~mm} /$ day.

The intensity of rainfall after landslide event on November 24, 2017 was decreased from $5.1 \mathrm{~mm} /$ day to $6.2 \mathrm{~mm} /$ day. On November 25 and November 26, 2017 the rainfall intensity was reached $4.2 \mathrm{~mm} /$ day to $6.2 \mathrm{~mm}$ /day. On November 27, 2017 the intensity of rainfall was increased sharply about $17.2 \mathrm{~mm} /$ day to $21.2 \mathrm{~mm} /$ day and $22.7 \mathrm{~mm} /$ day to $32.5 \mathrm{~mm} /$ day on November 28, 2017. Daily rainfall conditions during the landslide event in Talegong District, Garut Regency was shown in Figure 7.

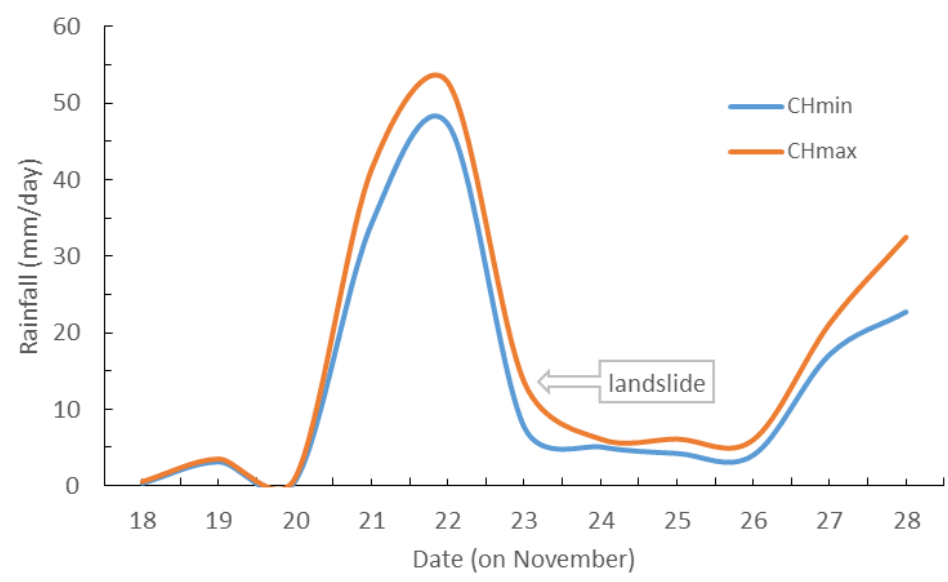

Figure 7. Accumulated daily rainfall intensity on November 18 to November 28, 2017 in Talegong District, Garut Regency as detected from Himawari-8 data

Landslide in four districts; Malangbong, Pasirwangi, Banjarwangi, and Cisewu have correspond with the day where the intensity of rainfall was maximum. Meanwhile for Talegong District, the landslide was occurred a day after its maximum.

Based on Himawari-8 rainfall data, the threshold of rainfall triggering landslide for five district could be determined as follows; Malangbong: $60.3 \mathrm{~mm} /$ day, Banjarwangi: $32.3 \mathrm{~mm} /$ day, Pasirwangi: $36.9 \mathrm{~mm} /$ day, Cisewu: $35.1 \mathrm{~mm} /$ day, and Talegong: $52.8 \mathrm{~mm} /$ day. It was assumed that one to three days before landslide the rainfall condition was relatively in low intensity up to high intensity.

\section{Landslide Risk Analysis in Garut Regency}

The slope of five observed districts were vary, about $12 \%$ (gentle slope) to $40 \%$ (very steep slope) with a elevation from 570 $\mathrm{m}$ to $1,325 \mathrm{~m}$ above sea level. Land use type was dominated by mixed plantation crops and agriculture lands. As in general, the higland of Garut Regency also dominated by regosol/sandy soil type (about $42 \%$ ) which had vulnerable by landslide characteristics. The lithological condition of the bedrock was in the form of breccias (about 28\% of the area) which vulnerable to erosion. Furthermore, the information about vulnerability area to landslide could be derived from these geophysical parameters.

Based on the landslide risk map as shown in Figure 8 (Source: Hikmah, 2016) and data processing for five investigation districts, the information of vulnerability area to landslide could be determined, as summarized in Table 1. It was noted that four observed districts were classified as moderate area of vulnerability while the 
other, Malangbong was classified as an area with a low vulnerability to landslide, relatively.

Table 1. Vulnerability area to landslide

\begin{tabular}{lcccc}
\hline \multicolumn{1}{c}{ Districts } & Very Low & Low & Moderate & High \\
\hline Banjarwangi & $0.0 \%$ & $16.7 \%$ & $82.0 \%$ & $1.3 \%$ \\
Cisewu & $0.0 \%$ & $15.3 \%$ & $82.8 \%$ & $1.8 \%$ \\
Malangbong & $1.4 \%$ & $53.2 \%$ & $44.7 \%$ & $0.7 \%$ \\
Pasirwangi & $0.0 \%$ & $14.7 \%$ & $84.2 \%$ & $1.1 \%$ \\
Talegong & $0.0 \%$ & $22.4 \%$ & $76.6 \%$ & $1.0 \%$ \\
\hline
\end{tabular}

Source: Hikmah, 2016 and data analysis

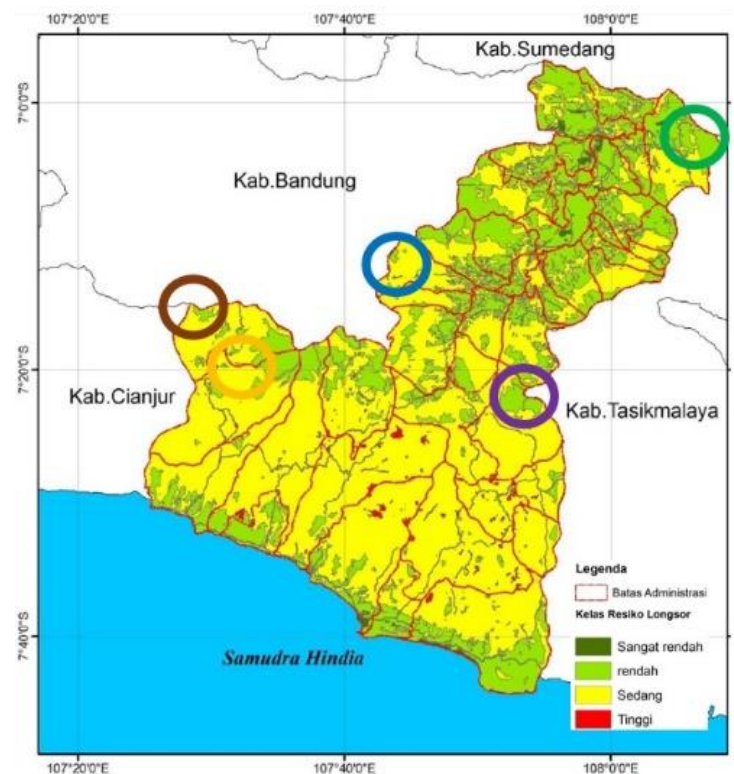

Figure 8. Landslide risk map for Garut Regency (Source: Hikmah, 2016)

Green circle in Figure 8 showed the Malangbong District. Meanwhile Pasirwangi, Cisewu, Talegong and Banjarwangi Districts were noted by blue, orange, brown and purple circles respectively. Figure 9.a and Figure 9.b showed the check field location to landslide in Cikarag Village, Malangbong District and Girimukti Village, Cisewu District, Garut Regency.

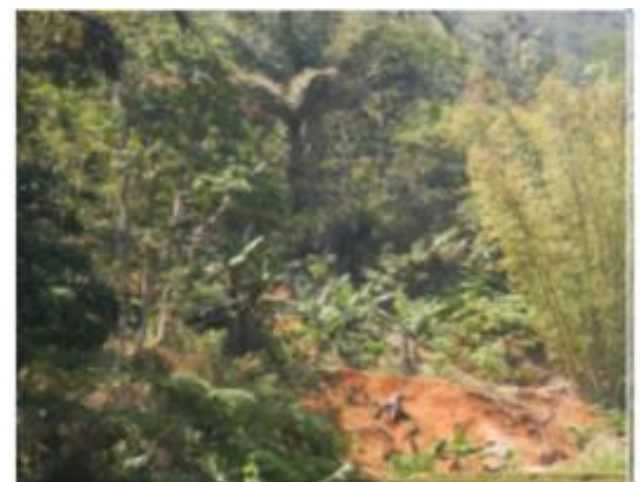

9.a

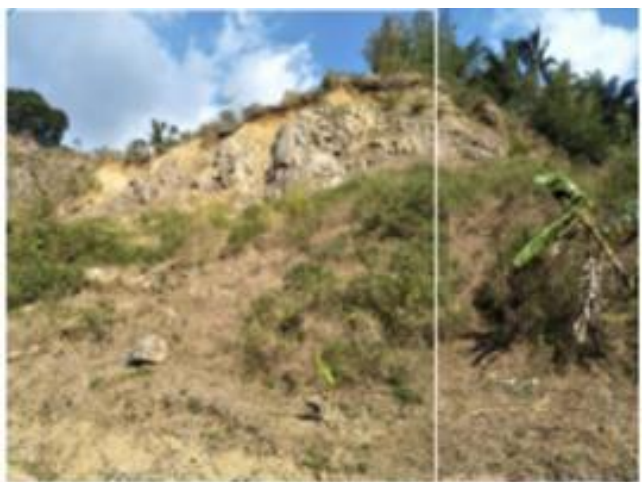

9.b

Figure 9. Check field location to landslide in Cikarag Village, Malangbong District (9.a) and Girimukti Village, Cisewu District (9.b), Garut Regency 


\section{CONCLUSION}

Rainfall thresholds for landslide activity was determined by the intensity maximum of daily accumulation based on Himawari- 8 data. The threshold of rainfall triggering landslide for five district were obtained as follows, for Malangbong District: $60.3 \mathrm{~mm} /$ day, Banjarwangi District: $32.3 \mathrm{~mm} /$ day, Pasirwangi District: 36.9 $\mathrm{mm} /$ day, Cisewu District: $35.1 \mathrm{~mm} /$ day, and for Talegong District: $52.8 \mathrm{~mm} /$ day. Landslide in four districts; Malangbong, Pasirwangi, Banjarwangi, and Cisewu have corresponded with the day where the intensity of rainfall was maximum. Meanwhile for Talegong District, the landslide was occurred a day after its maximum.

\section{ACKNOWLEDGEMENT}

We thank Director of Remote Sensing Application Center, National Institute of Aeronautics and Space (LAPAN) for supporting this research.

\section{REFERENCES}

BNPB, 2014. Indeks Risiko Bencana Indonesia Tahun 2013. Direktorat Pengurangan Risiko Bencana, Deputi Bidang Pencegahan dan Kesiapsiagaan.

BNPB. (2017). Data Bencana Tahun 2017. Pusat Data, Informasi dan Humas Badan Nasional Penanggulangan Bencana. ISBN : 978 - 602 - 5693 - 04 - 5

Corominas, J., \& Moya, J. (1996). Historical landslides in the Eastern Pyrenees and their relation to rainy events. In: Landslides (Chacon J, Irigaray C, Fernandez T, eds). Rotterdam: A.A. Balkema, 125-132

Crosta, G. B., \& Frattini, P. (2003). Distributed modelling of shallow landslides triggered by intense rainfall. Nat. Hazard Earth. Sys. Sci., 3(1-2), 81-93

Gairola, R. M., Varma, A. K., Prakash, S., \& Mahesh, C. (2013). Development of Rainfall Estimation Algorithms for Monitoring Rainfall Events over India Using KALPANA-IR Measurements on Various Temporal and Spatial Scales. J. Chem. Inf. Model, 53, 1689-1699.
Guzzetti, F., Peruccacci, S., Rossi, M., \& Stark, C. P. (2007). Rainfall thresholds for the initiation of landslides in central and southern Europe. Meteorol Atmos Phys., 98, 239-267

Hadmoko, D. S., Lavigne, F., \& Sartohadi, J. (2017). Spatio-Temporal Distribution of Landslides in Java and the Triggering Factors. Forum Geogr., 31(1). doi.org/10.23917/forgeo.v31i1.3790

Hikmah, N. (2016). Studi Perbandingan Pemetaan Risiko Bencana Longsor Berbasis Pendekatan Normatif Dan Pendekatan Kuantitatif Di Kabupaten Garut. Thesis. Institut Pertanian Bogor

Huang, R. (2014). Engineering Geology for Society and Territory. Eng. Geol. Soc. Territ., 8(2), 13-33. https:/ / doi.org/10.1007/978-3-31909408-3

Kushardono, D. (2012). Kajian satelit penginderaan jauh cuaca generasi baru Himawari 8 dan 9. Inderaja, III(5), 41-49

Ma, Z., Maddy, E. S., Zhang, B., Zhu, T., \& Boukabara, S.A. (2017). Impact assessment of Himawari-8 AHI data assimilation in NCEP GDAS/GFS with GSI. J. Atmos. Ocean. Technol., 34, 797815. doi.org/10.1175/JTECH-D-160136.1

Marchese, F., Falconieri, A., Pergola, N., \& Tramutoli, V. (2018). Monitoring the Agung (Indonesia) ash plume of November 2017 by means of infrared Himawari 8 data. Remote Sens. 10. doi.org/10.3390/rs10060919

Marfai, M. A., Hadmoko, D. S., Sartohadi, J., Singh, L.P., Dewi, A., King, L., \& Mardiatno, D. (2008). Natural hazards in Central Java Province, Indonesia: an overview. Environ. Geol., 56, 335-351. doi.org/10.1007/s00254-007-1169-9

McColl, S. (2015). Landslide causes and triggers. In: Davies, T. (Ed.), Landslide Hazards, Risks, and Disasters. Elsevier.

Na, L., Zhang, J., Bao, Y., Bao, Y., Na, R., Tong, S., \& Si, A. (2018). Himawari-8 satellite based dynamic monitoring of grassland fire in China-Mongolia border regions. Sensors (Switzerland), 18. doi.org/10.3390/s18010276 
Nanda Alfuadi1, N., \& Wandala, A. (2016)., Comparative Test Of Several Rainfall Estimation Methods Using Himawari-8 Data. International Journal of Remote Sensing and Earth Sciences, 13(2), 95 - 104

Okumura, H., Sekiyama, T.., Khatri, P., Ogi, A., Nagao, T.M., Uchino, O., Murakami, H., Irie, H., Kikuchi, M., Yumimoto, K., Maki, T., Morino, I., Arai, K., \& Tanaka, T.Y. (2016). Aerosol data assimilation using data from Himawari-8, a nextgeneration geostationary meteorological satellite. Geophys. Res. Lett., $\quad 43, \quad 5886-5894$. doi.org/10.1002/2016g1069298

Richard M. Iverson, R. M. (2000). Landslide triggering by rain infiltration. Water Resources Research, 36(7), 1897-1910

Shang, H., Letu, H., Peng, Z., \& Wang, Z. (2018). Development of a daytime cloud and aerosol loadings detection algorithm for Himawari-8 satellite measurements over DESERT. Int. Arch. Photogramm. Remote Sens. Spat. Inf. Sci. ISPRS Arch. 42, 61-66. doi.org/10.5194/isprs-archives-XLII-3W5-61-2018
Sitorus, S. R. P., \& Pravitasari, A. E. (2017). Land Degradation and Landslide in Indonesia. Sumatra Journal of Disaster, Geography and Geography Education, 1, 61-71.

Wickramasinghe, C.H., Jones, S., Reinke, K., \& Wallace, L. (2016). Development of a multi-spatial resolution approach to the surveillance of active fire lines using Himawari-8. Remote Sens., 8, 1-13. doi.org/10.3390/rs8110932

Xu, C., Ma, S., Tan, Z., Xie, C., Toda, S., \& Huang, X. (2016). Landslides triggered by the $2016 \mathrm{Mj}$ 7.3 Kumamoto, Japan, earthquake. Landslides, 15(3), 551-564

Zhang, J., van Westen, C. J., Tanyas, H., Mavrouli, O., Ge, Y., Bajrachary, S., Gurung, D. R., Dhital, M. R., \& Khanal N. R. (2019). How size and trigger matter: analyzing rainfall- and earthquake-triggered landslide inventories and their causal relation in the Koshi River basin, central Himalaya. Nat. Hazards Earth Syst. Sci., 19, 17891805

Zhao, C., \& Lu, Z. (2018). Remote Sensing of Landslides - A Review. Remote Sens., 10, 279 